\title{
ROTULAGEM DE ALIMENTOS TRANSGÊNICOS: UM MECANISMO EFICAZ PARA A CIDADANIA PARTICIPATIVA
}

Bruno Valverde Chahaira

Mestre em Direito Negocial pela UEL e doutorando em Direito Constitucional pela Fac. Autônoma de Direito de São Paulo. Professor da Univ. Federal de Rondônia.

Valmir César Pozzetti

Mestre e Doutor em Direito Ambiental pela Université de Limoges/França. Professor Adjunto da Universidade do Estado do Amazonas; Professor Adjunto da Universidade Federal do Amazonas.

\section{Resumo}

Dentre as produçôes da novel Engenharia Genética, destaca-se a produção de alimentos transgênicos que consiste na técnica de manipulação de genes de um organismo doador a um organismo receptor diverso. Tais produçóes geram muitas polêmicas em virtude da falta de certeza cientifica em relação a possíveis prejuízos à saúde e o meio ambiente; pois recentemente, estâo sendo atribuídas a elas, a responsabilidade por contaminação de solos e o aparecimento de alergias e noveis doenças. Não obstante ao fato das incertezas que trazem, eles estáo sendo liberados para o plantio e consumo dos animais e dos humanos. Neste sentido, a legislação brasileira e a internacional determinam que o consumidor têm o direito de optar por consumir ou não um alimento transgênico, obrigando as empresas que produzem alimentos cuja composição contenha pelo menos $1 \%$ de transgenicidade, a rotulá-lo, inserindo em suas embalagens um símbolo que permita ao consumidor identificá-lo como tal e, a partir daí, decidir se quer ou não consumir tais alimentos. Assim, o objetivo deste trabalho é analisar as questôes que envolvem as incertezas científicas no tocante à produção e consumo dos Alimentos Transgênicos, evidenciando os benefícios da Rotulagem, permitindo ao consumidor o direito de escolha sobre o que quer e o que não quer consumir, consagrando a participação do consumidor no processo de cidadania democrática; comparando, neste aspecto, a legislação nacional com a legislaçáo internacional, verificando se é viável, ou não, dispensar a rotulagem ou, se dispensá-la, seria um retrocesso. A metodologia utilizada no presente trabalho é a do método dedutivo, onde se busca analisar os conhecimentos produzidos para se chegar a uma resposta satisfatória no tocante à participação democrática do cidadáo. Quanto aos 
meios, a pesquisa é bibliográfica, com utilização de doutrina, legislação e jurisprudência e, quantos aos fins, a pesquisa é qualitativa.

\section{Palavras-chave}

Alimentos transgênicos; Rotulagem; Direito a informação; Participação.

\section{Resumé}

Parmi les productions de nouvelle ingénierie génétique, il ya la production d'aliments transgéniques comprenant de la technique de manipulation génétique d'un organisme de donneur à un receveur organisme différent. Ces productions génèrent de nombreuses controverses en raison de l' absence de certitude scientifique concernant un éventuel dommage pour la santé et l'environnement; depuis peu, sont assignés à eux, le sol contamination responsabilité et l'émergence des allergies et des maladies nouvelle. Malgré le fait que les incertitudes qu'ils apportent, ils sont libérés pour la plantation et la consommation des animaux et des humains. En ce sens, la loi brésilienne et internationale exiger que le consommateur a le droit de choisir de consommer ou non un aliment génétiquement modifié, obligeant les entreprises qui produisent des aliments dont la composition contient au moins $1 \%$ transgenicidade, à étiqueter, en insérant dans son l'emballage d'un signe permettant au consommateur d'identifier comme tel, et à partir de là, décider ou non de consommer ces aliments. Ainsi, l'objectif de cette étude est d'analyser les questions entourant les incertitudes scientifiques concernant la production et la consommation d' aliments contenant des OGM, mettant en évidence les avantages de l'étiquetage, permettant aux consommateurs le droit de choisir ce que vous voulez et ce que vous ne voulez pas de consommer, consacrant la participation des consommateurs dans le processus de la citoyenneté démocratique; la comparaison à cet égard, la législation nationale avec le droit international, vérifier si cela est possible ou non de renoncer à l'étiquetage ou, si le rejeter, serait un pas en arrière. La méthodologie utilisée dans ce travail est la méthode déductive, où il cherche à analyser les connaissances produites pour arriver à une réponse satisfaisante au sujet de la participation citoyenne démocratique. Quant aux moyens, la recherche est la littérature, en utilisant la doctrine, la législation et de la jurisprudence et de la façon dont les extrémités, la recherche est qualitative.

\section{Mots-clé}

Aliments transgéniques; Étiquetage; Droit de l'information; Participation.

\section{Introdução}

Nas últimas décadas pode-se verificar uma grande evolução no campo da biotecnologia e, em especial, no campo de produção de alimentos transgênicos, oriundos da engenharia genética. 
A técnica consiste num processo de manipulação de genes de um organismo doador a um organismo receptor, que pode ser ou não da mesma espécie. Esse processo gera diversas discussões e dúvidas sobre a falta de certeza científica na produção destes alimentos e coloca a comunidade cientifica em alerta, pois náo se tem certeza de que esses organismos são inofensivos à saúde do consumidor e ao meio ambiente.

Os cientistas da área não conseguem garantir que eles são benéficos à saúde e ao meio ambiente. Há diversas discussóes sobre a contaminação do solo, no cultivo, e diversos relatos de doenças adquiridas pela ingestão destes alimentos.

Em virtude dessas incertezas, por cautela, a legislação brasileira determina que os alimentos que possuam composição de até 1\% de OGM - Organismos Geneticamente Modificados - devem ser identificados com a rotulagem, para permitir o direito de escolha do consumidor e, também, se houver problemas futuros de contaminação, se possa descobrir com precisáo e rapidez a origem do mal, podendo eliminar o produto do mercado e, ainda, socorrer a tempo as possíveis vítimas e o meio ambiente, buscando detectar-se o antídoto necessário.

Neste sentido, o Código de Defesa do Consumidor brasileiro prevê a obrigatoriedade de informação adequada e clara sobre todos os produtos, com especificação correta de quantidade, características, composição, qualidade, tributos incidentes e preço. Tal obrigatoriedade abrange também os Organismos Geneticamente Modificados e, dentre eles, os Alimentos Transgênicos.

Além disso, o Princípio do "Direito Meio Ambiente Equilibrado" às presentes e futuras geraçôes (art. 225, CF) abrange a saúde pública, a qual está diretamente ligada à comercialização de OGMS.

Por ser muito contestado os futuros efeitos que esses alimentos possam causar á saúde do consumidor e ao meio ambiente, a cautela exige que o consumidor seja informado de que o alimento que está sendo oferecido no mercado é transgênico, permitindo assim, o direito de escolha, de decisão, sobre o que quer consumir; pois o fato de decidir, ou escolher, o que quer ou não consumir, são direitos que integram a cidadania.

Entretanto, há uma grande pressão das empresas de biotecnologia, no sentido de que os Alimentos Transgênicos são seguros, que não causam mal à saúde e nem ao meio ambiente e que a rotulagem, além de assustar o consumidor, torna-o mais caro, pois o custo da rotulagem é considerável.

Mas as empresas de biotecnologia não conseguem provar essa "alegada segurança" e multiplicam-se os casos de contaminação e supostos prejuízos à saúde do consumidor, evidenciando que não há certeza cientifica sobre a sua segurança.

Entretanto, mesmo diante dessas incertezas, a Câmara de deputados federais aprovou no dia 27/04/2015 o Projeto de Lei no 4148/2008, que permite a dispensa às indústrias produtoras de alimentos transgênicos, de informarem no rótulo deste, que o produto 
comercializado tem origem transgênica. O texto será, agora, apreciado pelo Senado Federal, e está sendo identificado como PL no 34/2015.

Tal Projeto de Lei vai contra jurisprudência do Tribunal Regional Federal da Primeira Região (Apelação no 2001.34.00.022280-6), que assegurou que todo e qualquer produto geneticamente modificado ou contendo ingrediente geneticamente modificado seja devidamente informado. Além disso, o projeto atenta contra o direito de informação previsto na Constituição Federal e no Código de Defesa do Consumidor.

Dessa forma, o objetivo deste trabalho é analisar as questóes que envolvem as incertezas cientificas sobre a produção e consumo dos Alimentos Transgênicos, evidenciando os benefícios da Rotulagem para o direito de escolha do consumidor, como participe do processo democrático e confrontar o direito do cidadáo brasileiro com a legislação nacional e a legislação internacional e verificar se podemos ou não dispensar a rotulagem ou, se dispensá-la seria um retrocesso.

A metodologia utilizada no presente trabalho é a do método dedutivo, onde se busca analisar os conhecimentos produzidos para se chegar a uma resposta satisfatória no tocante à participação democrática do cidadão. Quanto aos meios, a pesquisa é bibliográfica, com utilização de doutrina, legislação e jurisprudência e, quantos aos fins a pesquisa é qualitativa.

Assim, a problemática que se levanta é : de que forma o consumidor pode decidir se quer ou não consumir alimento transgênico ? De que forma ele será informado e o seu direito de escolha será respeitado ? O presente trabalho se justifica, pois a discussáo, tanto acadêmica como social, é atual e extremamente importante para a sociedade; pois o que se coloca no centro das discussóes é o direito à saúde do consumidor e o direito de informação, para que este possa exercer o seu direito de escolha.

Este assunto é debatido, tanto no âmbito nacional como internacional, e hoje se coloca como um grande tema de discussão no Brasil. Por esse motivo, a pesquisa é importante, pois a pressão das empresas de biotecnologia é muito grande e a da bancada ruralista no Congresso Nacional, que propóe um retrocesso legal, é uma verdadeira afronta aos direitos já conquistados pelo consumidor, devendo ser denunciada e esclarecida.

A pesquisa busca, então, evidenciar a legislação existente, ressaltar as evidências de incerteza cientifica em relação aos alimentos transgênicos e ressaltar os benefícios da rotulagem para o consumidor; uma vez que a rotulagem permite a participação democrática deste, no tocante ao seu direito de escolha sobre o que vai comer e se quer ou não quer fazer uso do alimento transgênico.

\section{Rotulagem}

Ter informaçóes claras e precisas a respeito do alimento que se vai comprar ou consumir, é um direito inalienável do consumidor; pois dessa forma ele exerce o seu direito 
de livre escolha, optando conscientemente pelo que quer e pelo que não quer comer, garantindo a sua saúde.

Esta clareza na informação permite que ele não seja enganado ou que não lhe seja imposto, arbitrariamente, pelo fornecedor, um produto do qual não quer fazer uso.

No âmbito da alimentação, esse direito à informação tem uma dimensão maior, visto que vai refletir na sadia qualidade de vida do consumidor.

Em 1.962, a FAO - Organização das Naçóes Unidas para a Agricultura e Alimentação - e da OMS - Organização Mundial da Saúde (cuja função principal é a de proteger a saúde dos consumidores e assegurar práticas equitativas de comércio regional e internacional de alimentos), criaram um Programa de Normas Alimentares, que denominou-se Codex Alimentarius. Tal código está inacabado e vem se construindo ao longo dos tempos.

Esse código é que dita regras e padróes para o controle da produção de alimentos e comercialização de vitaminas e suplementos alimentares.

Dessa forma, o Codex Alimentarius assim define a rotulagem:

O rótulo é caracterizado como qualquer adesivo, marca, desenho, ilustração ou outro tipo de descrição escrita, impressa, gravada" e, "rotulagem é qualquer escrito, impresso ou gráfico, que está presente no rótulo que acompanha o alimento, ou é colocado próximo ao alimento, incluindo aquelas para proposta de promover suas vendas ou exposição.

Segundo a AGBio (2015, p.1), “os rótulos possuem três objetivos principais : 1) assegurar o fornecimento de informaçóes adequadas sobre a saúde e segurança; 2) proteger consumidores de indústrias de embalagens fraudulentas e ilusórias; e, 3) promover concorrência justa na comercialização do produto”.

Assim, os rótulos podem gerar efeitos que vão além do mero fornecimento de informações até a função de educar e alterar comportamentos.

Além disso, o rótulo deve ser apresentado de forma que seja entendido e lido pelo individuo comum, versando sobre as condições habituais de uso e compra; caso contrário, o fornecimento de suas informaçóes poderia ser considerado uma política regressiva, pois provê informaçôes que atingirão apenas consumidores pretensamente "educados".

De acordo com o artigo 2o do Decreto Federal no 4.680/03, “o produto que possuir acima de $1 \%$ de ingredientes transgênicos em sua composição deve ser rotulado; tanto os produtos embalados como os vendidos a granel ou in natura”. Vejamos:

Art. 2o Na comercialização de alimentos e ingredientes alimentares destinados ao consumo humano ou animal que contenham ou sejam produzidos a partir de organismos geneticamente modificados, com presença 
acima do limite de um por cento do produto, o consumidor deverá ser informado da natureza transgênica desse produto.

$\$ 1^{-}$Tanto nos produtos embalados como nos vendidos a granel ou in natura, o rótulo da embalagem ou do recipiente em que estáo contidos deverá constar, em destaque, no painel principal e em conjunto com o símbolo a ser definido mediante ato do Ministério da Justiça, uma das seguintes expressóes, dependendo do caso: "(nome do produto) transgênico", "contém (nome do ingrediente ou ingredientes) transgênico(s)" ou "produto produzido a partir de (nome do produto) transgênico”.

$\$ 2^{\circ}$ O consumidor deverá ser informado sobre a espécie doadora do gene no local reservado para a identificação dos ingredientes.

$\$ 3^{\circ}$ A informação determinada no $\$ 1^{\circ}$ deste artigo também deverá constar do documento fiscal, de modo que essa informação acompanhe o produto ou ingrediente em todas as etapas da cadeia produtiva. (gn)

Vê-se, então, que a norma exige que o recipiente ou a embalagem tragam no rótulo, em destaque, no painel principal juntamente com o símbolo, algumas expressóes padronizadas para informar a sua origem e composição transgênica, devendo conter a espécie doadora do gene e as seguintes informaçôes : "(nome do produto) transgênico"; "contém (nome do ingrediente ou ingredientes) transgênico(s)"; "Produto produzido a partir de (nome do produto) transgênico".

Além do rótulo em destaque, o Decreto determina que os alimentos geneticamente modificados também tragam um símbolo que o identifique como transgênico.

Tal símbolo, já foi definido pelo Ministério da Justiça : é um triângulo amarelo, com a letra " $T$ " dentro deste triângulo, podendo ser impresso também em preto sobre fundo branco, quando a embalagem não for colorida.

Esse símbolo deverá constar no painel principal da embalagem, que é o que fica voltado diretamente para o consumidor quando o produto está na prateleira. Isto é válido, também, para os alimentos destinados aos animais.

Quem fiscaliza o cumprimento da rotulagem dos alimentos transgênicos no Brasil, são todos os órgãos - responsáveis pela fiscalização de alimentos e os de defesa do consumidor - federais, estaduais e municipais : Vigilância Sanitária, Agricultura e os de Defesa do Consumidor.

Neste sentido, Lapeña (2005, p.157) esclarece que:

O desenvolvimento de uma política de rotulagem parte da premissa de que o consumidor tem o direito de saber o que está comprando e, conseqüentemente, consumindo ou usando. A maior fonte de informaçáo a esse respeito, está na rotulagem dos produtos. O consumidor, baseando-se 
na informação que existe no rótulo do produto, adota a decisão melhor e mais informada na hora de exercer seu direito de opção entre os produtos que se oferecem no mercado.

Assim, a derradeira função da rotulagem, estaria na função de educar o consumidor.

Por esse motivo, a participação democrática do cidadão se consagra neste ato de ser educado para poder participar do processo democrático; ou seja, a livre escolha, podendo decidir o que é melhor para a sua saúde.

Este entendimento está expresso no Código de Defesa do Consumidor, no caput do artigo $4^{\circ}$ e nos incisos III, IV, V e VI que estabelecem que a Política Nacional das Relaçóes de Consumo deve atender às necessidades do consumidor, primando pela transparência, boa-fé, educação e informação dos fornecedores e consumidores, controle de qualidade e segurança, bem como coibir todos os abusos, no mercado de consumo. Vejamos o texto legal:

Art. 40 A Política Nacional das Relaçôes de Consumo tem por objetivo $o$ atendimento das necessidades dos consumidores, o respeito à sua dignidade, saúde e segurança, a proteçáo de seus interesses econômicos, a melhoria da sua qualidade de vida, bem como a transparência e harmonia das relaçóes de consumo, atendidos os seguintes princípios:

(...) omissis

III - harmonização dos interesses dos participantes das relaçôes de consumo e compatibilização da proteção do consumidor com a necessidade de desenvolvimento econômico e tecnológico, de modo a viabilizar os princípios nos quais se funda a ordem econômica, sempre com base na boa-fé e equilíbrio nas relaçôes entre consumidores e fornecedores;

IV - educaçáo e informaçáo de fornecedores e consumidores, quanto aos seus direitos e deveres, com vistas à melhoria do mercado de consumo;

$\mathrm{V}$ - incentivo à criação pelos fornecedores de meios eficientes de controle de qualidade e segurança de produtos e serviços, assim como de mecanismos alternativos de solução de conflitos de consumo;

VI - coibição e repressão eficientes de todos os abusos praticados no mercado de consumo, inclusive a concorrência desleal e utilizaçáo indevida de inventos e criaçóes industriais das marcas e nomes comerciais e signos distintivos, que possam causar prejuízos aos consumidores; (gn)

Além disso, a rotulagem também ajuda a resolver problemas de responsabilidades que daí decorram; como por exemplo, o caso de alergias, toxidade ou troca acidental no nível de nutrientes dos alimentos que foram modificados geneticamente e que podem provocar situaçốes de perigo para a saúde dos consumidores. 
Há que se dizer, também, que a rotulagem permite a rastreabilidade detectando-se a origem do produto alimentar.

A rastreabilidade é mecanismo de identificação do alimento, desde a preparação da semente até a mesa do consumidor, registrando todos os processos pelos quais esse alimento sofreu desde a sua origem até o consumo final. Falaremos um pouco mais, no próximo capítulo, a respeito da rastreabilidade.

Os partidários da rotulagem entendem que a rotulagem dos alimentos transgênicos é muito importante no processo de responsabilização e que a rotulagem deveria ser responsabilidade daquele que introduz a nova tecnologia.

Coerente esse entendimento, uma vez que quem se beneficia da tecnologia, quem tem lucro com ela, deve arcar com ônus de bem informar sobre a origem do produto.

Entretanto, a rotulagem tem encontrado uma grande resistência, por parte das empresas de biotecnologia. Estas alegam que o processo de rotular é caro e além disso, a rotulagem acaba funcionando como um dispositivo de segurança, pois causam impacto negativo no consumidor que vê o alimento transgênico como algo perigoso.

Dessa forma, segundo elas, o produto fica mais caro e o rótulo acaba estabelecendo um preconceito em relação ao produto. Alegam, também, que não há porque rotular, uma vez que os alimentos transgênicos são equivalentes aos orgânicos.

Entretanto, essas alegaçóes das empresas de Biotecnologia náo podem subsistir, pois o perigo para a saúde do consumidor e para o meio ambiente não estão afastados, uma vez que não existe certeza cientifica de que esses alimentos são inofensivos à saúde do consumidor; ao contrário, há muitos rumores e diversos casos de alergia, câncer e contaminaçóes que estão sendo atribuídos a esses alimentos; logo, as ponderaçóes das empresas não encontram respaldo legal.

Em 2005, através de carta endereçada ao Ministro da Justiça, a ONG Greenpeace fez a denúncia de que a empresa Cargill não atendia à rotulagem estabelecida em Lei. Esta denúncia motivou uma Ação Civil Publica proposta pelo Ministério Público do estado de São Paulo. O Tribunal de Justiça de São Paulo, concedeu liminar para que em 30 dias às empresas Cargill e Bunge, que comercializavam os óleos de soja (marcas Soya e Liza), com mais de $1 \%$ de soja transgênica em sua produção, se adequassem aos ditames do Decreto no 4.680/03. Em 30 de janeiro de 2008 a açáo recebeu sentença, obrigando a todos a cumprir a Lei de Rotulagem, inclusive por esses fabricantes de óleo de soja.

Segundo Erickson, citado por Watanabe (2003, p. 107):

$\mathrm{Na}$ União Europeia, os alimentos que contêm percentagem superior a $1 \%$ de soja ou de milho geneticamente modificado, devem ser rotulados. No Japão, foi estabelecido o nível de $5 \%$ para a soja e, no caso do milho, 
devido ao potencial de polinização cruzada, nenhuma porcentagem foi estabelecida.

Vê-se, então, que muitos países entendem ser direito do consumidor, saber o que come e, esse cuidado está intimamente ligado à saúde pública, tendo em vista os diversos casos de contaminação ocorridos nesses países, tais como o sangue artificial e a doença da vaca louca. Por esses motivos, os consumidores tem sido encorajados a exigir os rótulos que identifiquem os alimentos desenvolvidos pela Biotecnologia.

E continua Watanabe (2003, p. 107):

Já nos Estados Unidos não existe nenhum requerimento obrigatório para rotulagem de alimentos GMs. O Food nad Drug Adminstration (FDA) considera que, se o alimento GM é substancialmente equivalente aos seus análogos convencionais, nenhum tipo de rotulagem é requerida, a não ser nos casos em que o conteúdo nutricional tenha sido alterado ou quando o produto contenha alergênicos conhecidos.

Vê-se, portanto, que a legislação americana é por demais "benevolente" com o fornecedor dos alimentos GMs. Está claro aqui, a transformação de um ato ilícito em ato lícito, pelo próprio Estado, que deveria proteger o cidadão; pois ainda não há certeza cientifica de que este alimento, mesmo com quantidade mínima de OGM, não trará efeitos danosos à saúde do consumidor. É o que tenta fazer hoje, a bancada ruralista no Congresso Nacional, que preocupa--se com os lucros que terão, não com a qualidade dos alimentos que forneceráo.

No que diz respeito aos alimentos GMs, há dois sistemas de rotulagem empregados : 1) o que considera que o rótulo deve conter informaçóes sobre o processo ou o procedimento utilizado para produzir ou elaborar o produto (posição adotada pelo Japão e Uniâo Europeia) e; 2) e o que considera que a rotulagem só irá ocorrer quando o produto final obtido difere significativamente da contra-parte convencional (composição, valor nutricional, proteína alérgica e intenção de uso).

Neste tocante, vejamos o que estabelece o Decreto no 4.680/2003:

Art. $2^{\circ} \mathrm{Na}$ comercializaçáo de alimentos e ingredientes alimentares destinados ao consumo humano ou animal que contenham ou sejam produzidos a partir de organismos geneticamente modificados, com presença acima do limite de um por cento do produto, o consumidor deverá ser informado da natureza transgênica desse produto.

$\$ 1^{\circ}$ Tanto nos produtos embalados como nos vendidos a granel ou in natura, o rótulo da embalagem ou do recipiente em que estáo contidos deverá constar, em destaque, no painel principal e em conjunto com o símbolo a ser definido mediante ato do Ministério da Justiça, uma das seguintes expressóes, dependendo do caso: "(nome do produto) 
transgênico", "contém (nome do ingrediente ou ingredientes) transgênico(s)" ou "produto produzido a partir de (nome do produto) transgênico".

$\$ 2^{\circ}$ O O consumidor deverá ser informado sobre a espécie doadora do gene no local reservado para a identificaçáo dos ingredientes.

$\$ 3$ - A informação determinada no $\$ 1$ 을 deste artigo também deverá constar do documento fiscal, de modo que essa informação acompanhe o produto ou ingrediente em todas as etapas da cadeia produtiva.

Art. $3^{\circ}$ Os alimentos e ingredientes produzidos a partir de animais alimentados com raçáo contendo ingredientes transgênicos deveráo trazer no painel principal, em tamanho e destaque previstos no art. 2o, a seguinte expressão: "(nome do animal) alimentado com raçáo contendo ingrediente transgênico" ou "(nome do ingrediente) produzido a partir de animal alimentado com ração contendo ingrediente transgênico".

Art. $4^{\circ}$ Aos alimentos e ingredientes alimentares que náo contenham nem sejam produzidos a partir de organismos geneticamente modificados será facultada a rotulagem "(nome do produto ou ingrediente) livre de transgênicos”, desde que tenham similares transgênicos no mercado brasileiro.(gn)

Independentemente do que está prescrito no caput do artigo $1^{\circ}$ do Decreto 4.680/03 (obrigação de rotular todos os produtos que contenham OGM), a rotulagem de transgênicos, está prevista, integralmente, no Código de Defesa do Consumidor - Lei 8.078/90, em seu artigo $6^{\circ}$, III, quando assegura que o consumidor tem direito à informaçáo clara, precisa e adequada, com especificaçáo de quantidade, caracterizaçáo, composiçáo, qualidade, preço e riscos que representam.

Outro dispositivo legal que estabelece a obrigatoriedade da rotulagem é o Decreto no $3.871 / 01$, que em seu artigo $1^{\circ}$, parágrafo $1^{\circ}$, determina que as expressóes "produto geneticamente modificado" ou "contém ingrediente geneticamente modificado" devem constar no rótulo de todo produto desta natureza. Já o parágrafo $2^{\circ}$ do mesmo artigo estabelece que estas informaçôes devem estar na língua portuguesa, com visibilidade adequada.

O Estado deve estar atento à rotulagem de alimentos transgênicos, pois o Decreto no 4.680/03, em seu artigo $4^{\circ}$, determina que os Ministérios representados na Comissáo serão os responsáveis pela fiscalização e pelo controle das informaçóes fornecidas aos consumidores.

Assim, a necessária rotulagem dos alimentos transgênicos é no sentido de informar os consumidores sobre aquilo que estão consumindo, sobretudo para preservar a saúde e a segurança alimentar, que é o principal interesse protegido pela rotulagem.

Importante destacar, neste contexto, o Princípio da Segurança Jurídica, que é um dos principais valores informadores da identidade político-filosófica que confere o 
adjetivo do Estado Democrático de Direito a um dado ordenamento. Este princípio está destacado, de maneira implícita no inciso XXXVI do artigo $5^{\circ} \mathrm{da}$ CF/88.

Além deste principio, importante destacar também o Principio da Supremacia do Interesse Público sobre o Privado. A função da Administração Pública é proteger a sociedade como coletividade, a liberdade de todos, contra o mau uso da liberdade de uns, ou de poucos.

Dessa forma, a rotulagem responderia à proteção da autonomia e da capacidade de escolha dos consumidores, ao ter em mãos informaçóes sobre os produtos, que consideram relevantes, na hora de escolher um determinado alimento.

Ainda temos que destacar um outro importante instrumento jurídico, que é a Lei no 9.677/98, que altera o capítulo III do Título VIII do Código Penal, incluindo a classificação dos delitos considerados hediondos, os crimes cometidos contra a saúde pública:

Art. 275 - Inculcar, em invólucro ou recipiente de produtos alimentícios, terapêuticos ou medicinais, existência de substância que não se encontra em seu conteúdo ou que nele existe em quantidade menor que a mencionada.

Pena - reclusão, de 1 (um) a 5 (cinco) anos, e multa. (gn)

Assim, pela interpretação da legislação acima, o produtor que deixar de cumprir a lei e não rotular adequadamente seus produtos, estará incurso na tipificação de crime hediondo, podendo responder criminalmente.

Verifica-se, então, que a legislação brasileira, no âmbito da rotulagem está consolidada, encontrando respaldo na Constituição Federal e em legislaçóes federais infra constitucional.

Entretanto, o deputado federal Luiz Carlos Heinze, propôs á Câmara do Deputados um PL - Projeto de Lei Federal, que estabelece a desobrigação da rotulagem de alimentos transgênicos no Brasil, alegando que eles não oferecem perigo, que são equivalentes aos alimentos orgânicos e que a rotulagem discrimina o produto. Tal PL foi aprovado pela Câmara de Deputados Federais e seguiu para a apreciação do Senado, agora como PL no $34 / 2015$.

A relatora deste PL, senadora Vanessa Grazziotin, do Amazonas, propôs uma consulta pública à população brasileira, a fim de que esta se manifeste em relação à rotulagem dos alimentos transgênicos. Tal atitude da senadora prestigia a democracia e participação do cidadão, permitindo que o povo brasileiro se manifeste a respeito do assunto, fortalecendo a cidadania.

Além da consulta pública, que objetiva permitir que os cidadãos optem, podemos observar que a exclusão da rotulagem dos alimentos transgênicos, fere diversos dispositivos 
federais e a Constituição Federal no tocante aos direitos fundamentais, que o Brasil consagra como cláusulas pétreas (direitos que não podem ser modificados ou excluídos).

O direito a saúde é também um direito fundamental do cidadão e este está assegurado na Constituição Federal, no capitulo relacionado ao meio Ambiente, bem como o dever do Estado de zelar por ela, in verbis:

Art. 225 - Todos têm direito ao meio ambiente ecologicamente equilibrado, bem de uso comum do povo e essencial à sadia qualidade de vida, impondo-se ao Poder Público e à coletividade o dever de defendê-lo e preservá-lo para as presentes e futuras gerações.

$\$ 1^{\mathbf{0}}$ - Para assegurar a efetividade desse direito, incumbe ao Poder Público:

V - controlar a produçáo, a comercializaçáo e o emprego de técnicas, métodos e substâncias que comportem risco para a vida, a qualidade de vida e o meio ambiente; (gn)

Um outro ponto a destacar é que, no Brasil, a análise dos processos de liberação de alimentos transgênicos é ato da CTNBio - Comissão de Biotecnologia, estabelecida pela lei No 11.105/2005, que tem a atribuição de analisar os processos de manipulação e construção genética desses alimentos e, liberá-los ou não, para o plantio e mercado consumidor.

Assim, cabe destacar a observação de Lisboa (2005, p. 61) a esse respeito, informando que "muitas matérias são votadas na CTNBio, com base no parecer dos relatores, sem que os conselheiros tenham tido tempo de ler os processos. Em alguns casos os processos sequer são distribuídos aos conselheiros e eles o aprovam após ouvir o parecer do relator".

Ou seja, a Comissão Técnica que deveria analisar com cuidado essas construçóes genéticas, não a analisam com o devido zelo e atenção. Será que precisaremos sofrer o horror que os europeus sofreram com o caso "vaca louca" para despertarmos sobre a importância da saúde?

Os europeus hoje exigem a rotulagem dos alimentos, exatamente porque perderam a confiança em suas agências sanitárias, de fiscalizar os alimentos, por isso, o próprio consumidor europeu decidiu ele mesmo fiscalizar o que quer e o que não quer consumir.

Verifica-se, então, que a rotulagem de alimentos transgênicos encontra guarida na Lei Maior brasileira, vez que as empresas de Biotecnologia, mesmo em meio a muitas discussóes sobre os perigos e doenças que estão sendo atribuídos aos OGMs, náo conseguiram trazer provas de que os alimentos transgênicos são inofensivos à saúde e ao meio ambiente. 
Dessa forma, veremos a seguir, como os organismos internacionais se posicionam em relação à rotulagem de alimentos transgênicos.

\section{A Rotulagem em Organismos Internacionais}

A oferta e o consumo de alimentos está intimamente ligado à saúde pública, que tem relação direta com o Direito Coletivo.

Neste sentido, os alimentos produzidos pela engenharia genética, provocam muitas discussões em todo o planeta, principalmente por parte da comunidade cientifica que não faz parte dos comitês das multinacionais da Biotecnologia.

A comunidade cientifica, independente, alega que é necessário a proteção da saúde, pois os estudos realizados pelas equipes de cientistas produtores náo analisa os efeitos na saúde do consumidor de forma global, e esses efeitos só serão percebidos a longo tempo, quando se conseguirá detectar os prejuízos irreversíveis.

Alegam esses organismos que o custo para provar a inocuidade desses alimentos deve ser do produto, pois o custo da contra-parte é muito caro e não deve recair sobre o Estado o ônus de fazer a contra prova. Esse ônus deve ser do produtor que obtém o lucro. Ao contrário, as empresas de biotecnologia se defendem, dizendo que seus produtos náo geram malefícios e que ninguém ainda provou o contrário.

Vejamos, a seguir, como alguns países e organismos internacionais se posicionam em relação à Rotulagem.

\subsection{A Rotulagem no Âmbito da OMC}

No âmbito da Organização Mundial do Comércio, a rotulagem de produtos no comércio internacional deve observar o Acordo sobre Barreiras Técnicas ao Comércio $\mathrm{TBT}^{1}$.

Esse acordo determina que a rotulagem dos OGMs e seus produtos derivados (se aplica, também, em matéria de regulações técnicas e padróes referidos, aos requisitos de envasamento e embalagem), deve ser feita com o fim de garantir o estabelecimento de normas técnicas em relação aos mesmos, que não implique numa barreira ao comércio e que seja aplicado conforme os princípios de "necessidade e proporcionalidade".

Segundo Lapeña (2005, p. 163), “de acordo com o TBT, os países devem adotar medidas protetivas à saúde, estabelecendo regras que assegurem o bem-estar de todos".

Neste sentido o TBT estabelece que:

1 TBT Agreement $=$ Acordo sobre Barreiras Técnicas ao Comércio. 


\section{PREÂMBULO (...) omissis}

$\$ 6^{\circ}$ Não se deve impedir a nenhum país que adote as medidas necessárias para assegurar a qualidade de suas exportaçóes, ou para a proteção da saúde e vida das pessoas e de seus animais ou a preservaçáo de seus vegetais, para a proteção do meio ambiente, ou para a preservação de práticas que possam induzir ao erro, aos níveis que se considerem apropriados, sob a condição de que não apliquem de forma tal que constitua um meio de discriminação arbitrária ou injustificada entre os países em que prevaleçam as mesmas condiçóes ou uma restriçáo encoberta de comércio internacional e que no mais estejam em conformidade às disposiçôes do presente acordo.

Importante destacar o conteúdo dos ítens 2.1 e 2.2 do TBT:

2.1- O produto importado receberá um trato nacional; as regulaçôes técnicas não poderão implicar obstáculos desnecessários ao comércio e não poderão ser mais restritivas do que o necessário para alcançar um objetivo legítimo, levando em conta os riscos que se criaria não os alcançando.

2.2 os objetivos legítimos incluem, entre outros, evitar práticas enganosas de comércio, proteger a saúde humana ou a segurança, o meio ambiente e a sanidade e plantas e animais. (gn)

Percebe-se, então, que a rotulagem está em perfeita harmonia com o TBT. A Organização Mundial do Comércio prestigia, dessa forma, a rotulagem dos alimentos transgênicos e o Brasil tem sua legislação em harmonia com essa norma internacional, o que permite que alguns países não ofereçam barreiras econômicas aos nossos produtos, vez que estáo em harmonia com os princípios da segurança jurídica e alimentar.

Vamos verificar agora, como a rotulagem está sendo observada e entendida pela comissão do Codex Alimentarius.

\subsection{Rotulagem na Comissão do Codex Alimentarius}

O Codex Alimentarius é uma instituição internacional criada pela FAO e OMS em resposta à necessidade global de harmonização de padróes e testes alimentares - resultado de um longo processo evolutivo envolvendo os mais diversos membros da Comunidade Internacional, em crises alimentares.

A importância do Codex Alimentarius, para a saúde dos Consumidores e para o Comércio Internacional de Alimentos, tem sido destacada por vários documentos internacionais, como a Conferência da FAO/OMS para nutrição, de 1.992; a Conferência Mundial de Alimentos da FAO, de 1.996; e o Acordo de Aplicação de medidas Sanitárias e Fotossanitárias do GATT², de 1.995.

2 GATT - General Agreement on tarifs and trade = Acordo Geral sobre Tarifas e Comercio. 
Em março de 2003, após várias consultas e exaustivos trabalhos, a Força-Tarefa do Codex para Alimentos Derivados da Biotecnologia, estabeleceu uma série de princípios relativos à análise de riscos à saúde humana que podem ser gerados por alimentos GMs (Geneticamente Modificados). Tais princípios dispóem que antes da comercialização é essencial uma avaliação, caso a caso, dos efeitos diretos e não-intencionais que os alimentos GMs podem gerar.

Entretanto, no âmbito do Codex Alimentarius, a controvérsia está sendo intensa no contexto de elaboração de um Anteprojeto de diretrizes para a Rotulagem de Alimentos, obtidos por meio de técnicas de modificação/Engenharia genética.

Conforme destacado no capitulo 1 desta pesquisa, o Codex define a rotulagem e estabelece os objetivos da mesma, destacando que ela é essencial à informação do consumidor para que ele tenha o direito de escolha, participe do processo de construção do sistema alimentar e de saúde pública.

Dessa forma, no tocante à oferta de alimentos transgênicos, como ainda não temos certeza cientifica sobre os seus efeitos maléficos ou benéficos à saúde humana e ao meio ambiente, eles devem ser rotulados, para proteger a saúde do consumidor e se permitir encontrar a cura de possíveis doenças oriundas dessa engenharia, caso tenhamos uma contaminação.

Vejamos agora, o sistema de rotulagem adotado na União Europeia.

\subsection{Rotulagem na União Européia}

O regime de regulação Europeu teve como antecedentes as crises alimentares da década de 1.990, em alguns países da União Europea.

Casos como a chamada crise da "Vaca Louca" ou a Encefalopatia Espongioforme Bovina - BSE no Reino Unido e, posteriormente, estendida à toda a Europa; a carne de frango intoxicada com dioxinas da Bélgica e por fim, a febre aftosa, gerou uma crise no sistema alimentar europeu, gerando alerta geral a respeito da oferta e consumo de alimentos.

Tais fatores, somados a uma inadequada ou inexistente comunicação do risco aos consumidores, em alguns dos casos mencionados, tiveram como resultado um grande receio e desconfiança dos consumidores europeus sobre as modificaçóes introduzidas na cadeia alimentar.

Além disso, estes casos implicaram em uma perda de confiança nas Agências Reguladoras Nacionais e em sua capacidade de zelar pelos interesses dos consumidores.

Com este temor, em 1.998 a Uniấo Europeia impôs moratória, de fato, na aprovação de novos OGMs, que foi suspensa e substituída por uma regulação mais estrita, 
a rotulagem e a rastreabilidade dos alimentos, que se traduz na descrição do caminho de um produto OGM da granja até a mesa, através de todo o processo de distribuição, processamento e manufatura até chegar ao produto final.

O artigo 21 da Diretiva 18/2001 da União Europeia obriga os Estados-Membros a tomar medidas para assegurar que, em todas as fases da colocação do produto no mercado, a rotulagem deve existir e ser garantida.

As sucessivas crises alimentares que ocorreram na Europa incentivaram a criação e o desenvolvimento de um novo e detalhado arcabouço jurídico sobre segurança alimentar e, em fevereiro de 2002 surge o Regulamento 178/2002, que cria a Autoridade Europeia para a Segurança dos Alimentos e estabelece os princípios gerais que devem reger a legislação alimentar no âmbito europeu.

Segundo Moraes (2004, p. 81) "o regulamento é aplicável a todas as fases da produção, transformação e distribuição de gêneros alimentícios e de alimentos para animais".

Já o Regulamento Europeu, no 1.830/2003, dispôe sobre a rotulagem de OGMs, e a rastreabilidade dos alimentos e produtos produzidos a partir deles; e o Regulamento 1.829/2003 dispóe sobre alimentos e produtos modificados geneticamente. Estes entraram em vigor a partir de abril de 2004, determinando que todos os alimentos derivados de OGM deverão ser etiquetados, existam ou não níveis detectáveis de DNA ou de proteínas de origem OGM no produto final.

Segundo Morais (2004, p. 81), "é permitida unicamente uma presença de OGM, e ainda acidental, de $0,9 \%$ nos alimentos. Acima deste limite, o produto deverá ser etiquetado como OGM".

Esta Regulação também impóe a rotulagem dos OGMs para o consumo animal, seguindo os mesmos princípios para consumo humano. Com isso, o regime europeu impóe um sistema de rastreabilidade "da granja à mesa”, de forma que todas as indústrias envolvidas na produção, armazenamento, transporte e processamento dos produtos derivados de OGM deverão ter um histórico de acompanhamento de produto e conservar seu registro por pelo menos cinco anos.

Importante destacar que a falta de uma uniformização, neste aspecto, está dificultando as transações comerciais internacionais. Aqui e ali o Brasil recebe uma comissão da Europa, da Rússia, da Noruega e outros, para atestar a fidedignidade e procedência da carne ou da soja, realizando embargos e proibição de compra dos alimentos, alegando barreiras sanitárias. Os empresários brasileiros, têm se revoltado, alegando que cumprem todas as exigências do mercado comum europeu e que a situação não pode continuar como está, querendo levar-se o caso à OMC.

Na França, o Decreto n 2009-45/2009 prevê a rotulagem dos organismos geneticamente modificados, postos à disposição de terceiros. Este Decreto altera o Código 
Ambiental, uma vez que as catástrofes conhecidas podem ser irremediáveis e Territórios inteiros possam ser sacrificados:

Art. D.532-17-1. - Quando os organismos geneticamente alterados são postos à disposição de terceiros tendo em vista a utilização confinada, como definido pelo artigo L. 532-2, para investigação, de desenvolvimento ou de ensino, devem conter um rótulo ou vir em acompanhados de um documento que indica:

- o nome do organismo geneticamente alterado;

- o nome e o endereço completo da pessoa responsável pela disponibilização;

- uma menção que especifica "Contém organismos geneticamente modificados".

Esta rotulagem deve ser completada, se existe espaço, observando-se as condiçôes dispostas no item 7, B do anexo IV, da Diretiva de 12 de Março de 2001 relativa à disseminação voluntária de organismos geneticamente modificados no ambiente. (gn)

Também foi inserido no Código Ambiental francês, o artigo D. 532-18-1t, que assim destaca:

Art.D. 532-18-1. - Quando os organismos geneticamente modificados, levados a efeito numa instalação que figura na nomenclatura das instalaçốes classificadas, são postos à disposição de terceiros, oriundos de uma utilização confinada, como definido pelo artigo L. 532-2, seráo acompanhados de um rótulo ou acompanhados de um documento que indica:

- o nome do organismo geneticamente modificado;

- o nome e o endereço completo do' empresário da' instalação classificada responsável pela disponibilização;

- uma menção que especifica "Contém organismos geneticamente modificados".

A aprovação, definida no artigo R. 515-32, precisa que esta rotulagem deve ser completada, em lugar conveniente, nas condiçôes previstas no item 7, B do anexo IV da diretiva de 12 de Março de 2001 relativa à disseminaçáo voluntária de organismos geneticamente modificados no ambiente. (gn)

Vê-se, então, que a legislação da França está em harmonia com a rotulagem, buscando preservar a saúde e o bem estar do consumidor, colocando a rotulagem como um dos mecanismos para a proteção do meio ambiente, vez que está tipificada dentro do código de meio ambiente da França. 
Vejamos, então, o tratamento jurídico à rotulagem, no âmbito do protocolo de Cartagena.

\subsection{Rotulagem no Protocolo de Cartagena (PCB)}

No Protocolo de Cartagena de Biossegurança - PCB, a rotulagem não é tratada sob o ponto de vista do consumidor. As normas referentes à rotulagem estão dirigidas aos operadores responsáveis pelo transporte e às autoridades alfandegárias e regulaçóes de medidas sanitárias e fitossanitárias, como mecanismo de manejo de risco na fase de transporte.

$\mathrm{O}$ artigo 18 deste protocolo refere-se principalmente à identificação de OGM na documentação que acompanha o movimento transfronteiriço.

Assim sendo, os Estados-Partes, de forma concreta, identificarão claramente, no caso dos OGMs destinados ao uso direto no alimento humano ou animal para processamento, que "pode conter" OGM e que "não estão destinados à introdução intencional no meio ambiente", assim como um ponto de contato para solicitar informaçáo adicional.

Segundo Lapeña (2005, p. 170):

Na primeira Conferência das Partes, que funcionou como reunião das partes do Protocolo (COP-MOP1 que aconteceu em fevereiro de 2004) entre os temas que permaneceram sem resolução na COP-MOP1, encontra-se a porcentagem ou a quantidade de material genético que pode ser considerado como livre de OGM para o transporte e a inclusão de documentação adicional".

E continua Lapeña (2005, p. 170) informando que:

há divergências nas regulamentaçôes de rotulagem de OGM, porque os objetivos das Partes são diferentes e contraditórios : enquanto o direito da OMC faz prevalecer o jogo do livre-mercado, uma concepção econômica do produto, no Protocolo, "universaliza o poder de polícia sanitária dos Estados".

Dessa forma, o que se verifica é que a Rotulagem é um efetivo meio de proteção à saúde do consumidor e permite a sua participaçáo inclusiva como efeito consequência, quando este exerce o seu direito de escolha e se torna partícipe do processo de cidadania.

Logo, a rotulagem possibilita ao consumidor a escolha de alimentos com características diferenciadas, com a capacidade de distinguir os produtos alimentares e a separação de seus atributos ao longo da cadeia produtiva.

Além disso, a rotulagem também permite celeridade nos processos de, em caso de contaminação e epidemias alimentares, descobrir-se rapidamente a causa do dano, 
ou seja, qual a sua origem; pois é através da rotulagem que se pode rastrear a criação e produção do alimento transgênico, conforme exporemos no próximo capitulo desta pesquisa.

\section{A Rastreabilidade dos Alimentos Transgênicos}

Com o advento do Código de Defesa do Consumidor - Lei 8.078, de 11 de setembro de 1990, o Brasil experimentou uma profunda mudança nas relaçóes entre produtores, distribuidores e consumidores, inclusive no ramo da alimentaçáo; eis que então, a novel legislação trazia em seu bojo, o direito à informação do consumidor, quanto aos atributos de qualidade do produto consumido.

Segundo Pessanha (2005, p. 170), a norma estabelecia que, no caso de alimentos com mais de um ingrediente geneticamente modificado em sua composição, "o nível de tolerância estipulada se refere a cada um dos ingredientes isoladamente, isentando de rotulagem os produtos in natura e aqueles nos quais a presença de OGM não fosse detectada”.

O decreto presidencial no 4.680 de 24 de abril de 2003, estabelece que a rotulagem é obrigatória àqueles alimentos que contenham o percentual de $1 \%$ de transgenicidade em sua composição, inclusive os alimentos de origem animal, alimentados com transgênicos. O decreto exige, ainda, a identificação da espécie doadora do gene.

A Instrução Normativa Interministerial no 1 , de 01 de abril de 2.004, que esclarece o Decreto no 4.680/03, refere-se aos "alimentos e ingredientes alimentares destinados ao consumo humano ou animal, embalados, ou a granel ou in natura, que contenham ou sejam produzidos a partir de organismos geneticamente modificados, com presença acima de um por cento do produto".

Assim, a rotulagem permite a rastreabilidade dos alimentos em toda a cadeia produtiva, no sentido de se estabelecer a segurança dos alimentos e, em caso de urgência como o foi o da "Vaca Louca" na Europa, detectar-se imediatamente o foco gerador de problemas, na cadeia produtiva.

Segundo Pessanha (2005, p.88):

Atualmente, a preservação de identidade é empregada para identificar as variedades de grãos que oferecem aditivos relacionados ao conteúdo ou à composição dos produtos, sendo também aplicada na distinção dos métodos de produção, como os de alimentos orgânicos, ou referendar a origem geográfica de um produto.

Assim, a rastreabilidade é a habilidade de registrar o caminho, a aplicação e a localização de um produto com características especificas, e implica em instituir uma sistemática 
de registro e transmissão de informações sobre atributos específicos do produto por todas as etapas da cadeia produtiva, ou seja, da produção até a comercialização final.

A rastreabilidade pode ser utilizada pelos produtores agrícolas e indústrias agroalimentares como um instrumento de garantia para assegurar o valor adicionado dos produtos, tendo em vista a demanda dos consumidores por padrôes de proteção ambiental, bem-estar animal e qualidade alimentar mais altos, que muitas vezes excedem os mínimos legais requeridos. A certificação dos sistemas de produção orgânica funciona de modo equivalente.

Entre as empresas europeias, que anunciaram açóes neste sentido, segundo Pessanha (2005, p. 100):

Estão a Delhaize-Le-Lion, segundo maior varejista Belga; a Tesco, principal varejista no Reino Unido; a Aveve, principal produtora de raçóes da Bélgica; a Hendrix, terceira maior empresa no mercado belga; a Soya Helllas, principal importadora de soja na Grécia; a Pingo Poultry.subsidiária da Nutreco; a Wiesenhof, principal produtor de aves da Alemanha; a Migros, principal varejista da suíça; o Superquinn, principal varejista da Irlanda; a Tagger, segundo produtor de raçôes para animais na Áustria; a Denofa, única indústria esmagadora da Noruega; o Grupo Felini, produtor italiano de carnes de aves e derivados; a Grampion Coubtry, primeiro grande produtor do Reino Unido de ração animal.

E continua Pessanha (2005, p. 100), informando que dentre as empresas que buscam garantir esse valor adicionado aos seus produtos, destaca-se, também:

A ação conjunta do Grupo McDonld’s na Alemanha, Reino Unido, Bélgica, Suíça, Dinamarca, Noruega, Finlândia e Suécia, que passou a exigir de seus fornecedores o uso exclusivo de ração animal e farelo de soja isentos de transgênicos e a aquisição de raçôes animais de zonas livres do cultivo de variedades geneticamente modificadas.

Nos Estados Unidos da América, destacam-se a Trader Joe’s, maior empresa varejista; a A. E. Staley and ADM (Archer Daniel's Midland), o segundo maior exportador de soja; e empresas de menor porte, como Zen-Noh, Consolidated Grain \& Barge, Clarkson Grain, que se especializaram na exportação de culturas não transgênicas.

No Brasil, a Sadia, maior empresa brasileira de exportação de carne de aves e derivados, foi a pioneira em implantar sistemas de rastreabilidade para excluir qualquer uso de soja, milho ou seus derivados transgênicos.

Em 30 de janeiro de 2002, em anúncio à imprensa, a Sadia informou que os seus produtos continham derivados de soja ou de milho não geneticamente modificados, tendo em vista a sistematizaçáo de procedimentos para evitar a aquisiçáo de matérias-primas modificadas geneticamente. 
Outra indicação de existência de iniciativas na área de preservação de identidade é a Carta da Cert ID ${ }^{3}$. A Cert ID afirma que já certificou um considerável volume de farelo de soja brasileiro como não-transgênico e se ofereceu para enviar uma lista dos fornecedores certificados de raçóes animais aos produtores de carne bovina e de aves, além de fornecer uma lista de empresas e importadores europeus de matérias-primas certificadas por ela, para a Europa.

A empresa brasileira Perdigão anunciou à imprensa, em 2 de setembro de 2002, o reforço do seu sistema de rastreamento, objetivando detectar a presença de OGMs nas diversas etapas da cadeia produtiva. Para tal, a empresa firmou convênio com a UFV (Universidade Federal de Viçosa), do estado de Minas Gerais.

Seguindo esta mesma linha de procedimento, várias empresas brasileiras estão fazendo uso do CertID, tais como : Laboratório AgroGenética, IMCOPA, COTRIMAIO, etc...

Desta forma, verifica-se que muitas empresa do ramo de alimentos estão preocupadas com a saúde do consumidor e com a qualidade dos alimentos que fornecem. E a rotulagem é um mecanismo de garantia de qualidade de seus produtos, vez que a permite a rastreabilidade e, com ela, se detectará os causadores dos prejuízos; prejuízos esses, que poderão levá-las á falência, em virtude de indenizações que estarão obrigadas a pagar, caso ocorram prejuízos à saúde do consumidor e ao meio ambiente.

\section{0 Direito à Informação no Brasil}

A rotulagem de alimentos transgênicos está ligada diretamente ao direito de informação que o consumidor tem, para poder realizar a escolha do produto que quer consumir.

No Brasil, a adequação ao Direito à Informação, previsto nas Diretrizes da Resolução no 39 da ONU, se deu com a inserção de alguns dispositivos da Carta Magna de 1.988, tais como os artigos 5, XIV; 170; 220; 221; e 225, \$ 1º, VI. Na Legislaçáo InfraConstitucional foi incorporado à Lei dos Agrotóxicos (Lei 7.802/89 e Na Lei de Política Nacional do Meio Ambiente (Lei 9.795/99, art. 6º $\$ 3^{\circ}$ e art. 10); na Constituiçáo Federal de 1.988.

$\mathrm{O}$ artigo $5^{\circ}$ da Constituição Federal do Brasil muito claro ao assegurar a todos os brasileiros e, inclusive aos estrangeiros, o acesso à informação.

Posteriormente, o Brasil editou uma legislação forte : o Sistema Jurídico de Proteção ao Consumidor, que através da Lei no 8.078, de 11 de setembro de 1990, concretiza essa proteção ao Consumidor, ratificados pelo Décimo Princípio da Declaração do Rio/92.

3 A Cert ID é uma empresa global que fornece certificação para agricultores, processadores, produtores, atacadistas e varejistas vinculados à indústria alimentar, inclusive programas de certificação para alimentos transgênicos, não-transgênicos, rastreabilidade e preservação de identidade. Ver: <www.cert-id. com>. 
Neste sentido, o artigo $6^{\circ}$ do CDC - Código de Defesa do Consumidor - Lei $n^{\circ}$ 8.078/90, garante o direito à proteção, à saúde, à segurança, o direito à proteção dos interesses econômicos, o direito à reparação dos prejuízos, o direito à informação e educação e o direito à representação.

Assim, cabe ao Estado intervir nas relaçóes de consumo, reduzindo o espaço da autonomia da vontade, impondo normas imperativas de maneira a restabelecer o equilíbrio e a igualdade de forças nas relaçóes entre consumidores e fornecedores.

Desta forma, segundo Dornelles (2003, p. 101-102), para serem comercializados, os alimentos transgênicos precisam passar por dois níveis de exigências :

1) é preciso ter cautela e evidenciar a responsabilidade do Estado em: controlar, fiscalizar e garantir a segurança geral da populaçáo consumidora destas novas variedades alimentícias. Assim, somente após toda uma série cautelosa e exaustiva, de análises e pesquisas que assegurem, razoavelmente, o pressuposto elementar da segurança ao consumidor, é que estas tecnologias podem alcançar o mercado consumidor;

2) para regular a comercialização dos alimentos transgênicos é preciso ter em meta o respeito aos direitos básicos do consumidor; quais sejam: à informação ampla, eficaz e veraz. Ressalte-se que esse direito passa a ser tanto mais necessário quanto maior o grau de novidade e risco do produto em questão. Quanto a isso, não há dúvidas de que os alimentos transgênicos são novidade e que apresentam alto grau de risco aos seus usuários.

Neste sentido, o inciso III do art. 6º do CDC - Código de Defesa do Consumidor - que destaca que "a informação adequada e clara sobre diferentes produtos e serviços, com especificação correta da quantidade, características, composição, qualidade e preço, bem como sobre os riscos que apresentem”, evidencia de forma clara, que o Princípio da Transparência rege o direito de informaçáo adequada e, além disso, que prima por uma publicidade com ampla veracidade em nome do respeito à boa-fé, em reconhecimento da situação de vulnerabilidade do consumidor no mercado.

E o CDC, também é claro ao registrar, no inciso III do artigo $4^{\circ}$, a necessidade da boa-fé nas relaçóes de consumo.

Desta forma, a ampla informação vai desde a informação na rotulagem até a abertura total e suficiente da informação útil e eficaz ao consumidor, tais como : a segurança à saúde, economicidade, desempenho, composição e precauçôes, informação esta promovida por meio da publicidade, manuais, serviço direto e gratuito de informaçóes telefônicas e sempre ao alcance dos mais simples consumidores.

Não obstante a isso, é preciso acrescentar que qualquer deficiência na concepção, na execução do dever de informar, redundará em responsabilidade civil objetiva do fabricante, 
do produtor (agrícola), do importador (art. 12, CDC) e do comerciante quanto à responsabilidade subsidiária dos fornecedores listados nos artigos 12 e 13 do CDC (fabricante e comerciante).

Assim, é importante evidenciar que os riscos "normais" e "potenciais" listados nos artigos. $8^{\circ}$ e $9^{\circ}$ do CDC, correm por conta do produtor/fornecedor e não do consumidor. Estes dois artigos evidenciam de forma clara que a saúde e a segurança do consumidor, por ingestão de produtos alimentícios, é responsabilidade do produtor/fornecedor e não do consumidor. Vejamos o teor do CDC:

Art. $8^{\circ}$ Os produtos e serviços colocados no mercado de consumo náo acarretaráo riscos à saúde ou segurança dos consumidores, exceto os considerados normais e previsíveis em decorrência de sua natureza e fruição, obrigando-se os fornecedores, em qualquer hipótese, a dar as informaçôes necessárias e adequadas a seu respeito.

Parágrafo único. Em se tratando de produto industrial, ao fabricante cabe prestar as informaçóes a que se refere este artigo, através de impressos apropriados que devam acompanhar o produto.

Art. $9^{\circ} \mathrm{O}$ fornecedor de produtos e serviços potencialmente nocivos ou perigosos à saúde ou segurança deverá informar, de maneira ostensiva e adequada, a respeito da sua nocividade ou periculosidade, sem prejuízo da adoção de outras medidas cabíveis em cada caso concreto. (gn)

Como os alimentos transgênicos ainda não provaram que são inofensivos ao meio ambiente e à saúde do consumidor, a rotulagem deve ser feita nos moldes do CDC.

Logo, o Direito à Informação do consumidor, sobre o produto que ele vai consumir, está consagrado na Resolução no 39, da 248 a Assembleia das Nações Unidas, que veio a ser concretizado no artigo $6^{\circ}$, inciso III do CDC brasileiro.

Este artigo, combinado com os artigos $8^{\circ}$ e $9^{\circ}$ do CDC, impóem ao fornecedor o dever de informar aos consumidores sobre os riscos anormais e previsíveis, dos produtos, em decorrência de sua natureza e fruição.

Segundo Morato (2003, p.2), “o acesso à informação (adequada, clara e precisa) sobre o produto colocado no mercado ou de serviço oferecido, suas características, qualidades e riscos, dentre outros, constitui direito básico e princípio fundamental do consumidor. Esta diretriz está expressa de forma clara no artigo 31 do CDC”.

A informação prestada no momento da contratação ou compra do produto, constitui componente necessário e essencial ao produto, que náo pode ser oferecido sem ela. Por conseguinte, toda informação prestada no momento, ou anterior ao início da contratação com o fornecedor, vincula o produto a ser colocado no mercado. Tal entendimento está consignado no artigo 30 do CDC. 
Logo, o CDC brasileiro, de forma exaustiva, estabelece que o Consumidor tem direito à informação : clara, suficientemente precisa e ostensiva na língua portuguesa, sobre todas as características do produto. Se o produto for importado (art. 31), deverá ter etiqueta com tradução e informações ao Consumidor, na língua portuguesa, informando itens básicos a respeito daquele produto, inclusive a informação de que trata-se de alimento transgênicos, quando o for.

É preciso ressaltar, também, que o Direito a Informação está atrelado ao Princípio da Transparência, estatuído no artigo $4^{\circ}$ do Código de Defesa do Consumidor, onde estabelece-se que "é obrigação do fornecedor, dar ao consumidor a oportunidade prévia de conhecer o produto, permitindo-lhe, no momento da contrataçáo, a ciência plena de seu conteúdo".

Logo, a ausência dessa informação pelos fornecedores, afronta o direito dos consumidores; pois não lhes esta sendo dada a oportunidade de tomarem conhecimento prévio do seu conteúdo;

O pressuposto da clareza das informações, aliado ao Princípio da Boa-fé objetiva (dever das partes de agirem conforme parâmetros de honestidade e lealdade), deve ser, acima de tudo, preservado, a fim de se estabelecer o equilíbrio e harmonia das relaçóes de consumo, coadunado com o interesse de ambas as partes, sem ocasionar-lhes qualquer lesão ou ameaça ao Direito.

É através do artigo $8^{\circ}$ do CDC que o Brasil tem conseguido coibir muitas práticas abusivas, como por exemplo, o caso de importação de milho transgênico da Argentina.

Conforme relata Dorneles (2003, p.101):

Em 03.01.2000, o Programa Estadual de Defesa do Consumidor do Estado do Rio Grande do Sul (PROCON/RS), por intermédio de seu Coordenador Executivo, Dr. Ben-Hur Rava, instaurou processo administrativo (no 4438-2177/00-4) contra a empresa AVIPAL S/A AVILCULTURA E AGROPECUÁRIA, após ter sido informado de que o Presidente do Tribunal Regional Federal da $4^{\mathrm{a}}$ Região, atendendo ao pedido de suspensão de execução de liminar nos autos do processo 2000.04.01.132912-9/RS, autorizou o descarregamento e internalização em solo brasileiro de uma carga de 11.309 toneladas de milho transgênico, provenientes da Argentina, transportados pela Ioannes NK, sem que fosse realizado qualquer Estudo Prévio de Impacto Ambiental.

A intervenção do Estado, neste caso, conseguiu garantir à sua população a alteração de um posicionamento de uma das principais empresas do País, na área de avicultura, de aceitar a utilização de produtos ou insumos contendo organismos geneticamente modificados em sua produção industrial. Tal situação só foi possível administrativamente, haja 
vista o forte poder de coerção conferido aos organismos estatais de defesa do consumidor no Brasil, a servir de paradigma aos demais países do Mercosul.

Nesse caso, o consumidor náo poderia desconhecer o fato que estava consumindo um alimento transgênico. Ele tem o direito de saber a procedência deste milho que estava sendo disponibilizado no mercado de consumo. De posse de tal informaçáo ele o consumiria se quisesse. Vê-se, portanto que, com a informação disponibilizada (rotulagem), o Consumidor exerce o seu direito de escolha, consagrando a cidadania participativa.

Nesse sentido, o artigo $9^{\circ}$ do CDC atribui ao fornecedor o dever de informar sobre os produtos que possam causar danos à saúde. $\mathrm{O}$ artigo $10^{\circ}$ do $\mathrm{CDC}$ também é bastante rico, pois proíbe o fornecedor de colocar no mercado, produto ou serviço nocivo ou perigoso à saúde.

$\mathrm{Na}$ mesma linha de proteção, no artigo 31 do $\mathrm{CDC}$, o legislador não se olvidou do dever do fornecedor de prestar informaçóes corretas, claras e precisas, facilitando a compreensão do consumidor no tocante à composiçáa do produto/serviço, no que tange à sua saúde alimentar.

No tocante à informação relativa aos alimentos transgênicos, o Decreto 4.680/03 estabelece em seu artigo $2^{\circ}$, que o consumidor deve ser informado da natureza transgênica do produto e sobre a espécie doadora do gene, no local reservado para a identificaçáo dos ingredientes $\left(\$ 2^{\circ}\right)$ e, ainda, que a informação de transgenia deve constar no documento fiscal, de modo a fornecer essas informaçóes a toda a cadeia produtiva.

Pois bem, desta tríade : consumidor, homens de Direito e homens públicos, resulta que o Direito do Consumidor, no Brasil, privilegia o direito destes a ter uma informação adequada; indo buscar reforço na sua estrutura lógico-jurídica que estabelece princípios basilares que norteiam este micro-sistema jurídico.

Dentre outros importantes princípios, pode-se afirmar que o Princípio da Ampla Informação está consignado no CDC (artigos 4o; $6^{\circ}$, III, $8^{\circ} ; 9^{\circ} ; 10^{\circ} ; 12^{\circ} ; 13^{\circ} ; 18^{\circ} ; 19^{\circ}$; $20^{\circ} ; 30^{\circ} ; 31^{\circ} ; 35^{\circ} ; 36^{\circ} ; 37^{\circ} ; 38^{\circ} ; 56^{\circ} ; 60^{\circ} ; 63^{\circ} ; 64^{\circ} ; 66^{\circ} ; 67^{\circ}$ e $72^{\circ}$, CDC) de forma clara.

O principio da ampla informação assume relevante papel no que diz respeito à liberdade no ato de consumo, pois evidencia o moderno conceito de cidadania (participaçáo consciente na formulação de políticas/decisões governamentais e mesmo no simples ato de consumir).

É princípio cuja responsabilidade é do Estado e dos Fornecedores, onde não se pode, de forma alguma, atribuir ao consumidor a responsabilidade de obter por si só, a informação. Logo, diante do que expusemos, a rotulagem de alimentos transgênicos, é um direito do consumidor que deve ser respeitado e executado pelos fornecedores de alimentos transgênicos, para consagrar um direito fundamental expresso na Constituição Federal e legislaçóes infra constitucionais. 


\section{Conclusões}

A qualidade de vida e a saúde do cidadão, bem como o meio ambiente ecologicamente equilibrado, não são matérias que possam ser relegadas pelo Poder Público; pois a Constituição Federal de 1988, estabelece cláusulas pétreas no tocante a essas matérias. Logo, é dever do Poder Público assegurar a efetividade deste direito.

Neste sentido, como o consumo de alimentos transgênicos está relacionado diretamente com a questão saúde, o consumidor tem direito a ter informação clara e objetiva sobre os produtos que está consumindo, pois os alimentos afetam diretamente a sua saúde.

Assim, o Poder Público, além de controlar a produção, a comercialização e o emprego de técnicas, métodos e substâncias que comportem risco para a vida, para a qualidade de vida e para o meio ambiente, deve impor aos fornecedores de bens e serviços, a obrigação de informar ao consumidor, de maneira ostensiva, todas as características do produto que quer comercializar no mercado, garantindo ao consumidor o direito de escolha e consequentemente, o de ter saúde.

Como os alimentos transgênicos são oriundos de técnicas de manipulação realizadas pela Engenharia genética e, não se tendo, ainda, certeza cientifica de que eles não causarão prejuízos ao meio ambiente e à saúde do consumidor, este tem o direito de ser informado sobre as especificidades desse produto, podendo a partir daí, optar se quer ou não consumi-lo.

A legislação brasileira e internacional estabelece que essa informação será feita através da rotulagem dos alimentos transgênicos oferecidos no mercado consumidor. Dessa forma, a Constituição Federal, em cláusulas pétreas, e na legislação infraconstitucional, consagram o direito do consumidor de ter essa informação e de poder escolher se quer ou não consumir alimento transgênico; permitindo que esse exerça, de forma participativa, o seu direito de escolha. Esse direito de escolha só será possível se os alimentos transgênicos forem rotulados, mecanismo que um Projeto de Lei tenta derrubar no Congresso Nacional, mas pelo que não encontra respaldo na legislação brasileira; se aprovado pelo Senado, certamente será julgado inconstitucional pela Corte maior brasileira; pois seria um retrocesso, além de afrontar a legislação vigente.

Assim sendo, pelo que pudemos observar, a rotulagem de alimentos transgênicos permite ao consumidor o direito de escolha e a participação inclusiva no processo de democracia e cidadania.

\section{Referências}

\section{AGBio. Is "GMO Free” an Additional “Organic”? On the Economics of Chain Segre-}

gation, disponível em: < www.agbioforum.org,> consultado em 11.05.2015. 
BRASIL, Constituição da República Federativa do. Congresso nacional, Brasília, 1.988. . Lei no 8.078/1990 - Código de Defesa do Consumidor. Congresso Nacional, Brasília, 1990 .

. Lei no 9.677 - Dos Crimes contra a Saúde Pública. Congresso Nacional, Brasília, 1998.

. Decreto no 3.871/2001. Rotulagem de OGMs. Presidência da República. Brasília, 2001.

. Lei no 11.105/2005 - Lei de Biossegurança. Congresso Nacional. Brasília, 2005.

. Decreto no 4.680/2003. Regulamenta o direito à Informaçáo no tocante aos Alimentos Geneticamente Modificados. Presidência da República. Brasília, 2003.

DORNELES, Renato Moreira. Tutela Administrativa dos Consumidores no Brasil como Paradigma aos Países do Mercosul. Editora Juruá. Curitiba.2003.

FAO. Organizaçáo das Naçóes Unidas para a Agricultura e Alimentação. Codex Alimentarius. Disponível em <http://codexalimentarius.net/standards/stand.htm>, consultado em 11 mai 2015.

FRANÇA. Decreto no 2009-45- Rotulagem de Alimentos Transgênicos. Informação disponível em: <www.legifrance.gouv.fr>, consultado em 11 mai 2015.

. Code de l'Environnement. Informação disponível em: <www.legifrance.gouv. fr>, consultado em 11 mai 2015.

GREENPEACE. Carta de Denúncia Alimentos Transgênicos. Disponível em < http:// greenpeace.org/br/brasil/transgenicos/noticias/cargill-se-rende-a-lei-leos $>$, consultada em 11 MAI 2015.

LAPEÑA, Isabel. Da Rotulagem de produtos Transgênicos.(Cap. 6) Coleção de Direito Ambiental. Organismos Geneticamente Modificados, organizado por Marcelo Dias Varella. Del Rey, Belo Horizonte, 2005. p.157.

LISBOA, Marijane. "Transgênicos no Brasil : o descarte da opinião Publica”. Artigo Publicado na Revista de Direito Ambiental Econômico, no 1, Sergio Antônio Fabris Editora. Porto Alegre. 2005, p.61.

MORAIS, Roberta Jardim de. Segurança e Rotulagem de Alimentos Geneticamente Modificados - SERAGEM. Rio de Janeiro, Forense : 2004.

MORATO, Maria Camila Ursia. Acesso a Informação. Informação disponível em < www. procon.goias.gov.br/artigodoutrinario/artigo_dout_20.htm>, consultado em 11 mai 2015. 
PESSANHA, Lavinia; WILKINSON John. Transgênicos, Recursos Genéticos e Segurança Alimentar. Ed. Autores Associados, Campinas/SP, 2005, p.59.

WATANABE, Edson. Avaliaçáo de Segurança dos Alimentos Geneticamente Modificados. Artigo publicado no livro Bioética e Biorrisco, Abordagem Transdisciplinar, organizado por VALLE, Silvio e TELLES, José Luiz, Interciência, Rio de janeiro, 2003, p.107. 